\title{
Efficiency of Water Hyacinth Biomass on Removal and Recovery of Chromium from Aqueous Solution through Column Study
}

\author{
E. Parameswari*, R. P. Premalatha, V. Davamani, P. Kalaiselvi and S. P. Paul Sebastian
}

Tamil Nadu Agricultural University, Coimbatore, India

*Corresponding author

\begin{tabular}{|l}
\hline Ke y w o r d s \\
Adsorption, Carbon, \\
$\begin{array}{l}\text { Chromium, } \\
\text { Recovery, } \\
\text { Regeneration }\end{array}$ \\
\hline Article Info \\
\hline $\begin{array}{l}\text { Accepted: } \\
\text { 15 December } 2019 \\
\text { Available Online: } \\
\text { 20 January } 2020\end{array}$ \\
\hline
\end{tabular}

\section{Keywords}

Adsorption, Carbon, Chromium,

Recovery,

Article Info

Accepted:

15 December 2019

Available Online:

\section{A B S T R A C T}

\section{Introduction}

Deterioration of water quality is of global concern today which dragged the people to an appalling situation. A diverse range of toxic heavy metal ions from the industrial discharge is a culprit in contaminating the water. The non- biodegradable and persistence nature of these contaminating metal ions urged the scientific community to work on their removal. Among the industries, tanneries contribute to chromium $(\mathrm{Cr})$ contamination on a larger scale as only 60-70 per cent of the $\mathrm{Cr}$ salts utilized in the tanning process reacts with the hides (Cauglhofer, 1986) and the remnant unutilized $\mathrm{Cr}$ left in tanning exhaust bath. The foresaid wastewater when allowed for depuration, results in the production of large quantities of sludge with $\mathrm{Cr}$. On an average, the effluent treatment plants of Tamil Nadu alone generate about 100 tonnes of sludge per day (Ahmed and Kashif, 2014). 
The disposal of this sludge in soils affects the environmental ambience and nearly 50,000 hectares of agricultural lands in vellore district of Tamil Nadu was severely affected by $\mathrm{Cr}$ where 60 per cent of the tanneries in india were located (Mahimairaja et al., 2000). This toxic metal enters the groundwater through leaching during seasonal rains with their concentration exceeding the maximum permissible limits recommended. It has been evident that a single tanning unit is capable of polluting the groundwater for a radius 7-8 kms (Parameswari, 2009; Brindha et al., 2010).To overcome the aforesaid lacuna and to sustain the environment, there is a necessity to remove these hazardous metal ions.

Both batch and column type adsorption experiments were carried out for removing that heavy metal. Adsorption capacity of the adsorbents for various toxic heavy metals at laboratory scale can be determined by batch type adsorption experiments but to know the rate of transport and diffusion of the metal ions in large scale pre-commercial treatment plants, column type of adsorption experiments will be more helpful. Comparing the batch mode experiments, column experiments are more useful as it can treat large quantities of contaminated water with specified adsorbent mass. Though this type of column experiments has greater advantage, only a few studies were reported for the heavy metal removal. The breakthrough curves obtained from the column experiment data can be utilized to study the column dynamics. By predicting this breakthrough point, a column can be designed with some up gradations for an industrial scale. A lot of batch type experiments were carried out to study the heavy metal removal from aqueous system, but no column study has been reported for $\mathrm{Cr}$ (III) removal from aqueous system utilizing water hyacinth biomass as adsorbent. To understand the applicability of the adsorbents in real situations, a series of desorption and degeneration experiments were carried out. Therefore, as an extension of our batch experiment, the present column study was formulated with objective to remove this toxic heavy metal from the aqueous solution by utilizing water hyacinth biomass as adsorbent.

\section{Materials and Methods}

\section{Preparation of water hyacinth biomass}

Water hyacinth plants were collected from Vaigai dam of Theni district, Tamil Nadu, India. The aquaphytes were washed to remove the sediments and other small floating fresh water aquatic weeds like Lemna sp. After washing, the plants were dried, ground with a blender and sieved (desirable size) to obtain powdered biomass as adsorbent.

\section{Experimental setup for column experiment}

The experimental design consists of glass column made up of borosilicate with the flow of adsorbate in downward mode as depicted in Fig. 1. The length and internal diameter of the column was about 52.7 and $4.6 \mathrm{~cm}$, respectively. The wire mesh $(0.2 \mathrm{~mm})$ and muslin cloth were placed at the bottom of each column and sand of $1 \mathrm{~cm}$ height each in the top and bottom of column were placed to avoid the washing of adsorbents. The column's bottom had a closed end and top of the column was closed with stop cork. The adsorbent [biomass $(106 \mathrm{~g})$ ] of $0.2 \mathrm{~mm}$ size was packed in a column with the bed height of $25 \mathrm{~cm}$ and the resulting bulk density was $0.255 \mathrm{~g} \mathrm{~cm}^{-3}$. The chromium solution of 500 $\mathrm{mg} \mathrm{L}^{-1}, \mathrm{pH}$ of 4.0 was fed in a downward mode (towards gravity) into the packed bed at varying flow rates of $0.5,1.0$ and $1.5 \mathrm{ml} \mathrm{min}^{-1}$ at laboratory conditions. The treated outlet samples were collected at regular time intervals to determine the residual $\mathrm{Cr}$ concentration. The column operation was 
ceased at a stage where there was no $\mathrm{Cr}$ sorption, and the inlet and outlet $\mathrm{Cr}$ concentration were equal (known as exhaustion of the column). The treated effluent samples from the column were analyzed using AAS (Perkin Elmer AA400). Break through curves were determined to assess the efficiency of the column adsorption study. Breakthrough curve is obtained by plotting $\mathrm{C}_{\mathrm{t}} / \mathrm{C}_{0}$ against time $\left(\mathrm{t}\right.$ ) (where $\mathrm{C}_{0}$ is the initial concentration of adsorbate in inlet and $\mathrm{C}_{\mathrm{t}}$ is the concentration of adsorbate at time, $\mathrm{t}$ ). Breakthrough point is the point where the ration of $C_{t}$ to $C_{0}$ varies from 0.05 to 0.90 . The $50 \%$ breakthrough time occurs when $\mathrm{C}_{\mathrm{t}} / \mathrm{C}_{0}$ is 0.50 .

\section{Modeling of column data}

The sorption capacity of $\mathrm{Cr}$ (III) onto water hyacinth biomass at different flow rates can be well explained by using mathematical models like Thomas model. It is explained below.

\section{Thomas model}

It is an indispensable model that helps in determining the maximum capacity of the $\mathrm{Cr}$ to the biomass in packed column. This model relies on langmuir isotherm and pseudo second order kinetics without any axial dispersion (Thomas, 1944). Thomas model for adsorption in a column is given by eqn. (1) (Chowdhury et al., 2012).

$\frac{\mathrm{C}_{\mathrm{t}}}{\mathrm{C}_{0}}=\frac{1}{1+\exp \left(\frac{K_{T} q_{0} x}{Q}-K_{T} \mathrm{C}_{0} t\right)} \longrightarrow(1)$

Where, $\mathrm{C}_{\mathrm{t}}$ is the $\mathrm{Cr}$ concentration in outlet at time $\mathrm{t}\left(\mathrm{mg} \mathrm{L}^{-1}\right), \mathrm{C}_{0}$ is the $\mathrm{Cr}$ concentration in the inlet $\left(\mathrm{mg} \mathrm{L}^{-1}\right), \mathrm{K}_{\mathrm{T}}$ is the kinetic rate constant of thomas model $\left(\mathrm{ml} \mathrm{mg}^{-1} \mathrm{~min}^{-1}\right), \mathrm{Q}$ is the flow rate $\left(\mathrm{ml}\right.$ minute $\left.{ }^{-1}\right), \mathrm{q}_{0}$ is the $\mathrm{Cr}$ adsorption capacity to the biomass $\left(\mathrm{mg} \mathrm{g}^{-1}\right), \mathrm{x}$ is the mass of the biomass $(\mathrm{g}), \mathrm{t}$ is the time (minutes). The constants $\left(\mathrm{K}_{\mathrm{T}}\right.$ and $\left.\mathrm{q}_{0}\right)$ in thomas model were determined from the slope and intercept of plot between $\ln \left(\mathrm{C}_{0} / \mathrm{C}_{\mathrm{t}^{-}}\right.$ 1) Vst.

\section{Desorption and regeneration of adsorbent}

After the sorption study, the column materials were washed with distilled water to remove the ions which were not bind to the biomass. To assess the $\mathrm{Cr}$ recovery from the biomass, a column desorption study was conducted with the metal desorbents. For this, the biomass loaded with $\mathrm{Cr}$ ions were desorbed by passing $0.1 \mathrm{M} \mathrm{HCl}$ at the flow rate of $0.5 \mathrm{ml}$ minute $^{-1}$ through the column operated under flow rate of $0.5 \mathrm{ml} \mathrm{min}^{-1}$ and $\mathrm{Cr}$ concentration of 500 $\mathrm{mg} \mathrm{L}^{-1}$ in a downward direction. The outlet was collected at regular time intervals (30 minutes) and was analyzed for $\mathrm{Cr}$ as explained in previous section. The experiment was continued till there was no prominent $\mathrm{Cr}$ concentration in outlet.

After elution, the packed column was washed with distilled water till the $\mathrm{pH}$ of the wash effluent became neutral. The regenerated biomass was again utilized in adsorption experiment to study its reusability. The adsorption capacity of the biomass was studied for successive three cycles of sorption and desorption.

The amount of $\mathrm{Cr}$ recovered from the biomass was calculated through eqn. (4)

Cr desorbed $(\%)=\frac{q_{d}}{q_{a}} \times 100 \longrightarrow$

Where $\mathrm{q}_{\mathrm{a}}$ is the amount of $\mathrm{Cr}$ adsorbed (mg), $\mathrm{q}_{\mathrm{d}}$ is the amount of $\mathrm{Cr}$ desorbed by $0.1 \mathrm{M} \mathrm{HCl}$ (mg)

The regeneration efficiency of the biomass was calculated through eqn. (5) 
Recovery efficiency $(\%)=\frac{q_{r}}{q_{0}} \times 100 \longrightarrow 5$

Where $\mathrm{q}_{\mathrm{o}}$ is the Cr adsorption capacity of the biomass originally $\left(\mathrm{mg} \mathrm{g}^{-1}\right), \mathrm{q}_{\mathrm{r}}$ is the $\mathrm{Cr}$ adsorption capacity of the regenerated biomass in successive regeneration cycles $\left(\mathrm{mg} \mathrm{g}^{-1}\right)$

\section{Results and Discussion}

Effect of solute flow rate on $\mathrm{Cr}$ (III) adsorption by water hyacinth biomass

The efficiency of the water hyacinth biomass packed in the column against varying flow rate of $\mathrm{Cr}$ (III) can be evaluated by the unit adsorption, time required for the breakthrough and shape of the breakthrough curve. Flow rate of the solute has a profound influence on the unit adsorption and percent removal of $\mathrm{Cr}$. The upshot of varying flow rates $(0.5,1.0$, $1.5 \mathrm{ml}$ minute $^{-1}$ ) with constant conditions of bed height $(25 \mathrm{~cm}), \mathrm{Cr}$ (III) concentration (500 $\mathrm{mg} \mathrm{L}^{-1}$ ) and solution $\mathrm{pH}$ (4.0) is depicted in Fig.2.

The experimental results revealed that unit adsorption of $2.95,1.12$ and $0.82 \mathrm{mg} \mathrm{Cr}$ (III) per gram of biomass at solute flow rates of $0.5,1.0$ and $1.5 \mathrm{ml}$ minute $^{-1}$ respectively (Table1). Higher unit adsorption of $\mathrm{Cr}$ (III) and per cent adsorption at lower flow rate of $0.5 \mathrm{ml}$ minute $^{-1}$ might be due to the availability of the sufficient residence or retention time for the solute molecule to make contact with adsorbent causing complete diffusion of solute molecules into the sorption sites (Muthusamy and Venkatachalam, 2015; Premalatha et al., 2018).

At higher flow rate $\left(1.5 \mathrm{ml}\right.$ minute $\left.{ }^{-1}\right)$, shorter contact time was needed to attain a exhaustion point whereas it was longer in case of lower solute flow rates $\left(0.5 \mathrm{ml}\right.$ minute $\left.^{-1}\right)$. Similar tendency was observed by Chowdhury and his co-workers in lignocellulose wastes
(Chowdhury et al., 2014). For adsorption of $\mathrm{Cr}$ (III) onto biomass, $50 \%$ breakthrough time and exhaustion time was $21 \mathrm{hrs}$ and $25 \mathrm{hrs} 30$ minutes respectively at solute flow rate of $0.5 \mathrm{ml}$ minute $^{-1}$. On increasing the flow rate, the exhaustion and breakthrough time gets declined i.e., at the flow rate of $1.0 \mathrm{ml}$ minute 1 , the $50 \%$ breakthrough and exhaustion time was $4 \mathrm{hrs}$ and $8 \mathrm{hrs}$ respectively. With the consideration of unit adsorption, percent removal, solute flow rate of $0.5 \mathrm{ml}$ minute $^{-1}$ was found be optimum. It was obvious from the figure that, increasing the flow rate of the $\mathrm{Cr}$ (III) makes sharper and steeper breakthrough curves whereas it was very gentle in case of lower flow rate of $0.5 \mathrm{ml}$ minute $^{-1}$. The prominent $\mathrm{S}$ - shaped breakthrough curve was noticed in the present study at solute flow rate of $0.5 \mathrm{ml}$ minute ${ }^{-1}$.

Considering the $\mathrm{Cr}$ adsorption capacity, the present column experiment recorded a very low unit $\mathrm{Cr}$ adsorption compared to batch studies (76.9 $\mathrm{mg} \mathrm{g}^{-1}$ ). Higher unit $\mathrm{Cr}$ adsorption in batch experiment might be due to continuous shaking of the adsorbent in the orbital shaker for a predetermined time which provoked the percent $\mathrm{Cr}$ adsorption leaving lesser quantities in the liquid phase.

Lower $\mathrm{Cr}$ adsorption capacity in the column mode might be the fact that, the concentration of the adsorbate molecules are increased continuously making the sorption, an irreversible process (Jain et al., 2015). Similarly, Setshedi and his co-workers reported a huge reduction in unit adsorption of $\mathrm{Cr}$ (VI) by adsorbent like carbon from stem wastes of sunflower plants and calcium alginate beads in column mode of experiment compared to batch studies (Setshedi et al., 2015). Apart from this, the possible reasons for reduced adsorption capacity are non static nature of adsorbate, tight packing and lack of stirring action in column mode of experiment (Goel et al., 2005). 


\section{Mathematical modeling}

The adsorption of $\mathrm{Cr}$ (III) onto biomass in a column study undergoes a dynamic equilibrium which can be better explained through mathematical models. In the present investigation, the data obtained from the above column study to assess the influence of solute flow rate on $\mathrm{Cr}$ (III) adsorption was fitted to models like Thomas models and the parameters determined from the above model was represented in Table 2.

The constant, $\mathrm{K}_{\mathrm{T}}$ of Thomas model for adsorption of $\mathrm{Cr}$ (III) onto biomass was $40 \mathrm{x}$ $10^{-4}, 40 \times 10^{-4}$ and $42 \times 10^{-4} \mathrm{~L} \mathrm{mg}^{-1} \mathrm{~min}^{-1}$ for flow rates of $0.5,1.0$ and $1.5 \mathrm{ml} \mathrm{minute}{ }^{-1}$ respectively. The $\mathrm{Cr}$ (III) sorption capacity $\left(\mathrm{q}_{\mathrm{o}}\right)$ was found to be 3043.6, 1197.9 and $874.7 \mu \mathrm{g} \mathrm{g}^{-1}$ at flow rates of $0.5,1.0$ and $1.5 \mathrm{ml}$ minute $^{-1}$ respectively in biomass. The qohad good agreement with experimental $\mathrm{q}_{0}$ ( $\mathrm{q}_{0 \text { exp }}$ ). i.e., the $\mathrm{q}_{0}$ for the adsorption for $\mathrm{Cr}$ (III) onto biomass predicted from the model was 3.04 $\mathrm{mg} \mathrm{g}^{-1}$ which was close to $2.95 \mathrm{mg} \mathrm{g}^{-1}$ recorded in the experiment. In Thomas model, on increasing the flow rate of the adsorbate, the values of $\mathrm{K}_{\mathrm{T}}$ increased but $\mathrm{q}_{0}$ decreased. This is in harmony with the research findings of Baral et al., (2009) for adsorption of $\mathrm{Cr}$ (VI) onto Salvinia. The suitability of Thomas model gives an idea that internal and external diffusion of solute molecules won't be restricted (Aksu and Gonen, 2004).

Table.1 Optimization of flow rate for adsorption of Cr (III) onto adsorbent

\begin{tabular}{|c|c|c|c|c|}
\hline $\begin{array}{c}\text { Flow rate }(\mathbf{m l} \\
\left.\text { minute }^{-\mathbf{1}}\right)\end{array}$ & $\begin{array}{c}\text { Metal adsorbed } \\
\left(\mathbf{m g ~ g}^{-1}\right)\end{array}$ & $\mathbf{t}_{\mathbf{0 . 5 b}}(\mathbf{h r s})$ & $\mathbf{t}_{\mathbf{e}}(\mathbf{h r s})$ & \% Adsorbed \\
\hline $\mathbf{0 . 5}$ & 2.95 & 21.0 & 25.5 & 81.7 \\
\hline $\mathbf{1 . 0}$ & 1.12 & 4.0 & 8.0 & 49.3 \\
\hline $\mathbf{1 . 5}$ & 0.82 & 2.0 & 6.0 & 32.1 \\
\hline
\end{tabular}

* $\mathrm{C}_{0}$ - Initial concentration of metal $\left(\mathrm{mg} \mathrm{L}^{-1}\right), \mathrm{t}_{0.5 \mathrm{~b}^{-}}$time taken for $50 \%$ breakthrough (hrs), $\mathrm{t}_{\mathrm{e}}-$ time taken for exhaustion (hrs)

Table. 2 Thomas model constants at different flow rates

\begin{tabular}{|l|c|c|c|}
\hline \multicolumn{1}{|c|}{ Constants } & FR- 0.5ml minute & FR- 1.0ml minute & FR- 1.5ml minute \\
\hline Thomas model & & & \\
\hline $\mathbf{K}_{\mathbf{T}}\left(\mathbf{L ~ m g ~}^{-1} \mathbf{m i n}^{-1}\right)$ & $40 \times 10^{-4}$ & $40 \times 10^{-4}$ & $42 \times 10^{-4}$ \\
\hline $\mathbf{q}_{\mathbf{0}}\left(\boldsymbol{\mu} \mathbf{g ~ g}^{-\mathbf{1}}\right)$ & 3043.6 & 1197.9 & 874.7 \\
\hline $\mathbf{q}_{\mathbf{0} \text { exp }}\left(\boldsymbol{\mu g} \mathbf{g ~ g}^{-\mathbf{1}}\right)$ & 2947.9 & 1115.3 & 816.5 \\
\hline $\mathbf{R}^{\mathbf{2}}$ & 0.972 & 0.993 & 0.877 \\
\hline
\end{tabular}


Table.3 Adsorption of $\mathrm{Cr}$ onto adsorbent and desorption with $0.1 \mathrm{M} \mathrm{HCl}$ in 3 consecutive cycles

\begin{tabular}{|c|c|c|c|c|c|c|}
\hline Cycle & $\mathbf{t}_{\mathbf{0 . 5 b}}(\mathbf{h r s})$ & $\mathbf{t}_{\mathbf{e}}(\mathbf{h r s})$ & $\begin{array}{c}\text { Adsorption } \\
\text { capacity (mg g }\end{array}$ & $\begin{array}{c}\mathbf{\%} \\
\text { Adsorption }\end{array}$ & $\begin{array}{c}\mathbf{\%} \\
\text { Desorption }\end{array}$ & $\begin{array}{c}\text { Regeneration } \\
\text { efficiency (\%) }\end{array}$ \\
\hline $\mathbf{1}$ & 21.0 & 25.5 & 2.95 & 81.7 & 57.3 & - \\
\hline $\mathbf{2}$ & 12.5 & 15.0 & 1.85 & 55.5 & 30.4 & 62.7 \\
\hline $\mathbf{3}$ & 3.0 & 8.5 & 0.42 & 28.0 & 14.5 & 23.1 \\
\hline
\end{tabular}

Fig.1 Experimental setup of column experiment

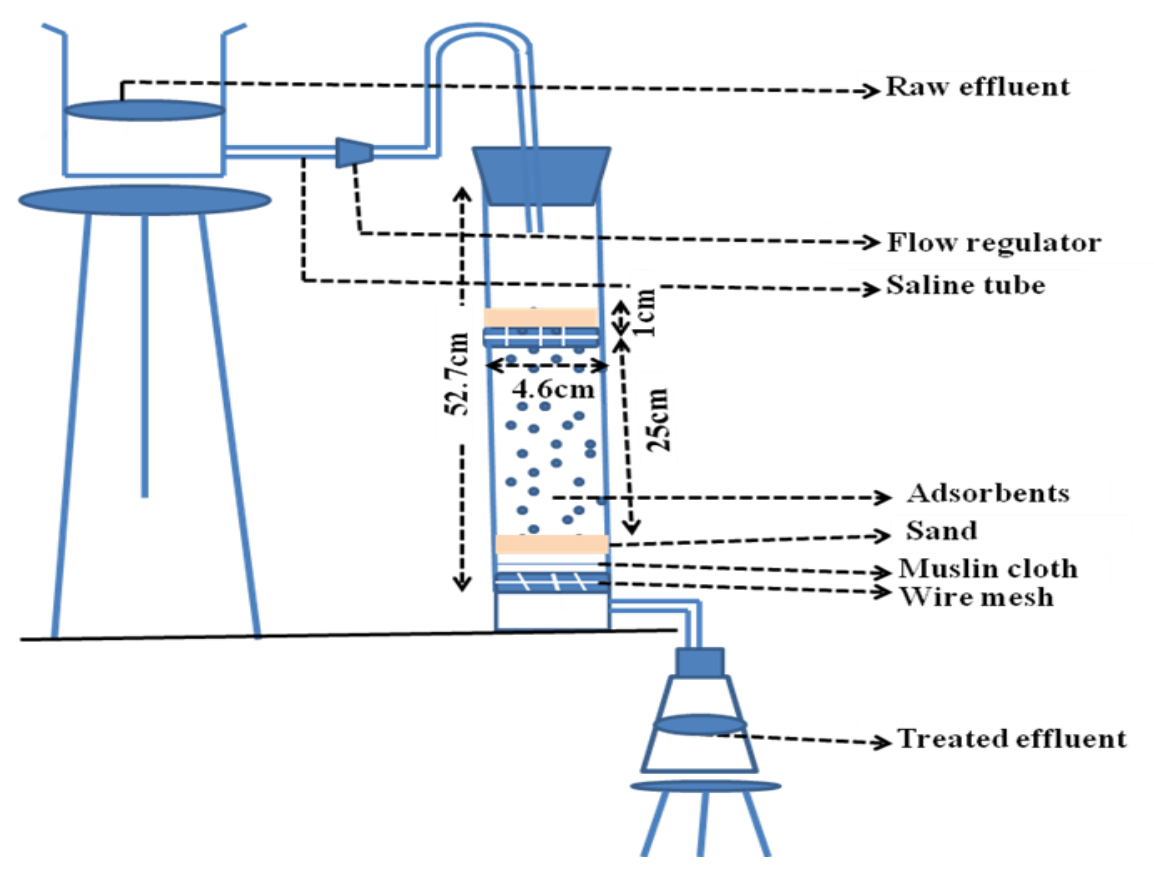

Fig.2 Breakthrough curve for varying solute flow rates at initial Cr(III) concentration of $500 \mathrm{mg} \mathrm{L}^{-1}$ and bed height of $25 \mathrm{~cm}$

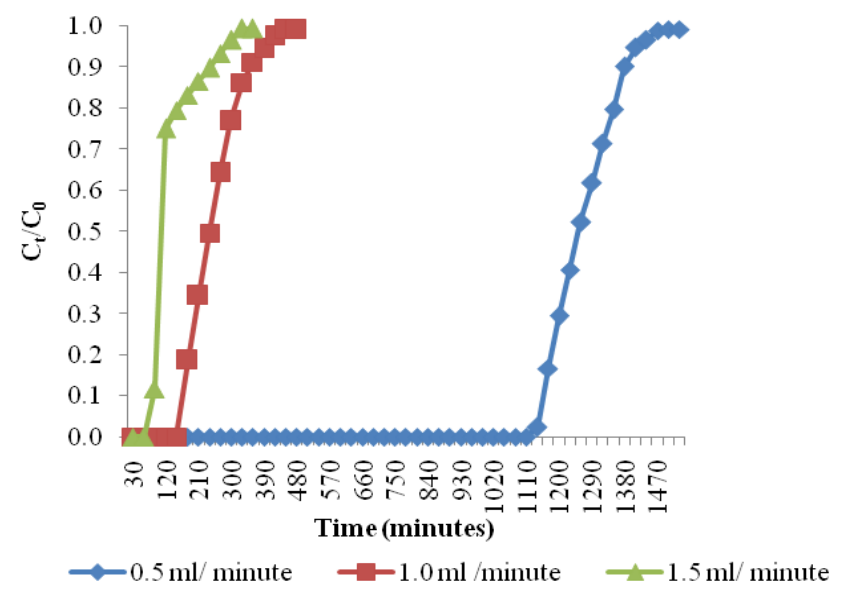




\section{Desorption and degeneration of biomass}

For a biosorption experiment, regeneration of the adsorbents for the successive reuse should be considered. As the regeneration cycle proceeds, the per cent sorption of $\mathrm{Cr}$ onto biomass gets declined which might be due to the reduced per cent desorption of $\mathrm{Cr}$ from the adsorbate sorbed biomass. From the experiment, it was clear that as regeneration cycle proceeds, the percent $\mathrm{Cr}$ adsorption, breakthrough and exhaustion time gets reduced. Similar findings were reported by Sivaprakash and his co-workers in their study on biosorption of $\mathrm{Cu}$ (II) from aqueous solution (Sivaprakash et al., 2010). This decline in the percent sorption in subsequent sorption cycles might be due to the structural cell wall breakdown or damage to binding sites aggravated by desorbing agents or blockage of the binding sites or due to the lack of the eluant's suitability reducing the number of sites available for successive sorption (Lezcano et al., 2011). Considering the regeneration capacity, the sorption and desorption experiment was continued for 3 cycles.

A lot of desorption experiments has been carried in past utilizing acids, base and complexing agents but acids were found be better performing with higher per cent desorption of cationic heavy metals (Stirk and Van Staden, 2002). Hence in the present investigation, the mineral acids were utilized as the desorbing agents. The breakthrough time, exhaustion time, $\mathrm{Cr}$ adsorption capacity, $\% \mathrm{Cr}$ adsorption, \% $\mathrm{Cr}$ desorption and regeneration efficiency calculated for three cycles is given in Table3. The per cent $\mathrm{Cr}$ adsorbed and desorbed was found be 81.7 and $57.3 \%$ respectively in cycle 1 whereas it was declined to 28.0 and $14.5 \%$ in cycle 3 . The regeneration efficiency was found to be 62.7 $\%$ cycle 2 which was declined to $23.1 \%$ in cycle 3 . The parameters like breakthrough time, $\mathrm{Cr}$ adsorption capacity and \% $\mathrm{Cr}$ adsorption declined on increasing the regeneration cycles which shows the deterioration of the sorption sites present in the biomass. The decline $\mathrm{Cr}$ adsorption capacity and per cent adsorption might be due to the reduction in the per cent $\mathrm{Cr}$ desorption from biomass.

In conclusion, the water hyacinth biomass was utilized in a column experiment for $\mathrm{Cr}$ (III) removal. The solute flow rate of $0.5 \mathrm{ml}$ minute $^{-1}$ was found to be optimum in fixed bed column experiment. Thomas model was found to highly suitable which gave an idea that internal and external diffusion of solute molecules won't be restricted. From the regeneration studies, it was evident that $0.1 \mathrm{M}$ $\mathrm{HCl}$ had greater tendency to desorb $\mathrm{Cr}$ level. Thus, it can be concluded that water hyacinth biomass can be effectively utilized for Cr (III) removal in fixed bed column mode and this technology can be upgraded to larger scale.

\section{Acknowledgment}

The authors thank the Science and Engineering Research Board (YSS/2015/001432), Department of Science and Technology for financial assistance.

\section{References}

Ahamed, M.I.N and Kashif, P. M. 2014. Safety disposal of tannery effluent sludge: Challenges to researchers- A review. International journal of Pharma Science and Research, 5(10), 733-736

Ahmad, A. and Hameed, B.2010.Fixed-bed adsorption of reactive azo dye onto granular activated carbon prepared from waste. J. Hazard. Mater., 175(1-3), 298303.

Aksu, Z., and Gonen, F. 2004. Biosorption of phenol by immobilized activated sludge in a continuous packed bed: prediction 
of breakthrough curves. Process Biochem., 39(5), 599-613.

Aldor, I., Fourest, E., and Volesky, B. 1995. Desorption of cadmium from algal biosorbent. Can. J. Chem. Eng., 73(4), 516-522.

Baral, S., Das, N., Ramulu, T., Sahoo, S., Das, S., and Chaudhury, G. R. 2009. Removal of $\mathrm{Cr}$ (VI) by thermally activated weed Salvinia cucullata in a fixed-bed column. J. Hazard. Mater., 161(2-3), 1427-1435.

Brindha, K., Elango, L. and Rajesh, V.G. 2010. Occurrence of chromium and copper in groundwater around tanneries in Chromepet area of Tamil Nadu, India. Indian Journal of Environmental Protection, 30(10), 818-822

Cauglhofer, J. 1986. Environmental aspects of tanning with chromium. J. Soc. Leather Technolo. Chem., 70, 11-13.

Chowdhury, Z. Z., Hamid, S. B. A., and Zain, S. M. 2014. Evaluating design parameters for breakthrough curve analysis and kinetics of fixed bed columns for $\mathrm{Cu}$ (II) cations using lignocellulosic wastes. BioResources, 10(1), 732-749.

Chowdhury, Z. Z., Zain, S. M., Khan, R. A., Rafique, R. F., and Khalid, K. 2012. Batch and fixed bed adsorption studies of lead (II) cations from aqueous solutions onto granular activated carbon derived from Mangostana garcinia shell. BioResources, 7(3), 2895-2915.

Goel, J., Kadirvelu, K., Rajagopal, C., and Garg, V. K. 2005. Removal of lead (II) by adsorption using treated granular activated carbon: batch and column studies. J. Hazard. Mater., 125(1-3), 211-220.

Han, R., Wang, Y., Zhao, X., Wang, Y., Xie, F., Cheng, J., and Tang, M. 2009. Adsorption of methylene blue by phoenix tree leaf powder in a fixed-bed column: experiments and prediction of breakthrough curves. Desalination, 245(1-3), 284-297.

Jain, M., Garg, V., Kadirvelu, K., and Sillanpaa, M. 2015. Combined effect of sunflower stem carbon-calcium alginate beads for the removal and recovery of chromium from contaminated water in column mode. Ind. Eng. Chem. Res., 54(5), 1419-1425.

Lata, S., and Samadder, S. 2014.Removal of heavy metals using rice husk: a review. International Journal of Environmental Research and Development. 4(2), 165170.

Lezcano, J., Gonzalez, F., Ballester, A., Blazquez, M., Munoz, J., and GarciaBalboa, C. 2011.Sorption and desorption of $\mathrm{Cd}, \mathrm{Cu}$ and $\mathrm{Pb}$ using biomass from an eutrophized habitat in monometallic and bimetallic systems. J. Environ. Manage., 92(10), 2666-2674.

Mahimairaja, S., Sakthivel, S., Divakaran, J., Naidu, R. and Ramasamy, K. 1998. Extent and severity of contamination around tanning industries in Vellore district. In proceedings of workshop on Towards Better Management of Soils Contaminated with Tannery Wastes, Tamil Nadu Agricultural University, Coimbatore, India, ACIAR Publication No 88, pp.75-82.

Muthusamy, S., and Venkatachalam, S. 2015.Competitive biosorption of $\mathrm{Cr}$ (VI) and $\mathrm{Zn}$ (II) ions in single-and binary-metal systems onto a biodiesel waste residue using batch and fixed-bed column studies. RSC Advances, 5(57), 45817-45826.

Parameswari, E. 2009. Impact of agricultural drainage water on crops under sequential biological concentration system and use of nanoparticles for wastewater treatment (Doctoral dissertation, Ph. D. Thesis, Tamil Nadu Agric. Univ., Coimbatore).

Premalatha R.P., E. Parameswari, 
V.Davamani, P. Malarvizhi and S. Avudainayagam. 2019.Biosorption of Chromium (III) from Aqueous Solution by Water Hyacinth Biomass. Madras Agric. J., 106(1-3): 12-21

Setshedi, K. Z., Bhaumik, M., Onyango, M. S., andMaity, A. 2015. Highperformance towards $\mathrm{Cr}$ (VI) removal using multi-active sites of polypyrrolegraphene oxide nanocomposites: batch and column studies. Chem. Eng. J., 262, 921-931.

Sivaprakash, B., Rajamohan, N., and Sadhik,
A. M. 2010. Batch and column sorption of heavy metal from aqueous solution using a marine alga Sargassum tenerrimum. Int. J. Chem. Tech. Res., 2(1), 155-162.

Stirk, W. A., and Van Staden, J. 2002. Desorption of Cadmium and the reuse of brown seaweed derived products as biosorbents. Botanica Marina, 45 : 9 -16

Thomas, H. C. 1944. Heterogeneous ion exchange in a flowing system. J. Am. Chem. Soc., 66(10), 1664-1666.

\section{How to cite this article:}

Parameswari, E., R. P. Premalatha, V. Davamani, P. Kalaiselvi and Paul Sebastian, S. P. 2020. Efficiency of Water Hyacinth Biomass on Removal and Recovery of Chromium from Aqueous Solution through Column Study. Int.J.Curr.Microbiol.App.Sci. 9(01): 1093-1101. doi: https://doi.org/10.20546/ijcmas.2020.901.124 